\title{
Can overtourism be managed? Destination management factors affecting residents' irritation and quality of life
}

\author{
Tanja Mihalic and Kir Kuščer
}

Tanja Mihalic and Kir Kuščer are both based at the School of Economics and Business, University of Ljubljana, Ljubljana, Slovenia.
Received 30 April 2020 Revised 29 June 2020 18 August 2020

26 September 2020

13 October 2020

20 October 2020

21 October 2020

Accepted 21 October 2020

(C) Tanja Mihalic and Kir Kuščer. Published by Emerald Publishing Limited. This article is published under the Creative Commons Attribution (CC BY 4.0) licence. Anyone may reproduce, distribute, translate and create derivative works of this article (for both commercial and non-commercial purposes), subject to full attribution to the original publication and authors. The full terms of this licence may be seen at http://creativecommons.org/licences/by/4.0/ legalcode

Funding: This work was supported by the Slovenian Research Agency under grant P5-0117

Declaration of Interest: This research is based on data commissioned by a public tender of DMO Tourism Ljubljana (2018)

\begin{abstract}
Purpose - This paper aims to present a model to survey if effective destination management can manage (unsustainable) overtourism from the perspective of residents' quality of life (QOL).

Design/methodology/approach - A constructivist approach, based on factors taken from conceptual overtourism model (Mihalic, 2020), was used to propose an overtourism QOL management model. Relationships among the factors were analysed with a path analyses model with two second-order latent factors. The model was tested in a real setting, the city of Ljubljana.

Findings - The proposed theoretical model is comprised of five factors: positive tourism impacts, negative tourism impacts, irritation with overtourism, residents' QOL and destination management. Empirical tests confirmed the model. Positive tourism impacts positively affected residents' QOL via destination management. Negative tourism impacts created overtourism-based resident irritation and negatively impacted their QOL.
\end{abstract}

Research limitations/implications - The model was limited to one group of sustainable tourism stakeholders: residents of a destination. The sustainability performance of tourism was only assessed based on residents' QOL.

Practical implications - The proposed model adds to the conceptual knowledge of tourism and may be useful for (sustainable) destination managers to monitor the existence and causes of overtourism and may help to focus efforts to manage the causes of overtourism irritation and improve residents' QOL.

Originality/value - Overtourism is a concern for residents of tourism destinations who become irritated by unsustainable tourism impacts on community resources and their QOL. The suggested model is the first to address destination management's ability to manage unsustainable overtourism.

Keywords Quality of life, Destination management, Ljubljana, Overtourism, Residents'satisfaction, Sustainable-responsible tourism

Paper type Research paper

题目：过度旅游可以管理吗? 影响居民恼怒和生活质量的目的地管理因素

设计/方法/路径：：本文采用建构主义的方法, 基于概念性的过度旅游模型 (Mihalic, 2020年) 中的因素, 提出了过度旅游中居民生活质量 $(Q O L)$ 管理模型。这些因子之间的关系是通过对包含两个二阶潜在因 子的模型的路径分析得到的。该模型在卢布尔雅那市的真实情况中进行了测试。

目的：：本文提出了这样一个模型, 从居民的生活质量 ( $Q O L)$ 角度出发, 调查有效的目的地管理是否可 以管理（不可持续的）过度旅游。

结果：：理论模型由五部分组成：正面的旅游影响, 负面的旅游影响, 过度旅游带来的恼怒, 居民的生活质 量和目的地管理。实证检验证实了该模型。积极的旅游业通过目的地管理对居民的生活质量产生了积极 影响。负面的旅游影响造成了基于过度旅游的居民恼怒情绪, 并对其生活质量产生了负面影响。

䂰究局限性/应用：：该模型仅基于一个可持续的旅游业利益相关者：目的地居民。旅游业的可持续发展 绩效仅根据居民的生活质量来评估。

实际应用：：社会和实际意义：提出的模型增加了旅游的概念性知识, 并且可能有助于 (可持续) 目的地 管理者监督过度旅游的存在和原因, 并且集中精力管理过度旅游引起的居民恼怒情绪, 并改善居民的生活 质量。 
原创性/价值：：对于旅游目的地的居民来说, 过度旅游是一个令人担忧的问题, 他们因不可持续的旅游业 对社区资源及其生活质量的影响而感到不快。本模型是第一个解玦目的地管理机构管理不可持续的过度 旅游的能力的模型。

关键词：：可持续负责任的旅游; 过度旅游; 目的地管理;生活质量; 居民满意度㥗怒; 卢布尔雅那

文章类型 : 硏究型论文

Se puede gestionar el exceso de turismo? Factores de gestión del destino que afectan a la irritación y la calidad de vida de los residentes

Diseño/metodología/enfoque : Para proponer un modelo de gestión del sobreturismo QOL, se utilizó un enfoque constructivista, basado en factores tomados del modelo conceptual de sobreturismo (Mihalic, 2020). Las relaciones entre los factores se analizaron con un modelo de análisis de rutas con dos factores latentes de segundo orden. El modelo se probó en un escenario real, la ciudad de Ljubljana.

Propósito : En este documento se presenta un modelo para estudiar si una gestión eficaz del destino puede gestionar el exceso de turismo (insostenible) desde la perspectiva de la calidad de vida de los residentes (QOL).

Hallazgos : El modelo teórico propuesto comprende cinco factores: impactos positivos del turismo, impactos negativos del turismo, irritación por el exceso de turismo, calidad de vida de los residentes y gestión del destino. Las pruebas empíricas confirmaron el modelo. Los impactos positivos del turismo afectaron positivamente la calidad de vida de los residentes a través de la gestión del destino. Los impactos negativos del turismo crearon una irritación de los residentes basada en el exceso de turismo y tuvieron un impacto negativo en su calidad de vida.

Limitaciones/implicaciones de la investigación : El modelo se limitaba a un grupo de interesados en el turismo sostenible: los residentes de un destino. El desempeño de la sostenibilidad del turismo sólo se evaluó en base a la calidad de vida de los residentes.

Implicaciones prácticas : Implicaciones sociales y prácticas: El modelo propuesto contribuye al conocimiento conceptual del turismo y puede ser útil para que los gestores de destinos (sostenibles) vigilen la existencia y las causas del exceso de turismo y pueda ayudar a centrar los esfuerzos en la gestión de las causas de la irritación del exceso de turismo y mejorar la calidad de vida de los residentes.

Originalidad/valor : El exceso de turismo es una preocupación para los residentes de los destinos turísticos que se irritan por los impactos insostenibles del turismo en los recursos de la comunidad y su QOL. El modelo sugerido es el primero que aborda la capacidad de la gestión del destino para gestionar el sobreturismo insostenible.

Palabras clave : Turismo responsable y sostenible (TRS), Turismo excesivo, Gestión de destinos, Calidad de vida, Satisfacción/irritación de los residentes, Ljubljana

Tipo de artículo : Trabajo de investigacion

\section{Introduction}

Destination management is paramount for quality of life (QOL)-centred sustainable tourism implementation. Poorly developed sustainability awareness (Lew, 2020) has resulted in a narrow understanding of sustainable tourism. This understanding is primarily concentrated on three pillars of sustainability, namely, natural, socio-cultural and economic resources (Bramwell et al., 2017; Wall, 2020). A destinations' natural and socio-cultural environments are attractive tourism resources that belong to the destination communities. Overtourism is a media term that reflects unrestricted tourism growth, leading to mass tourism. Unsustainable crowding and excessive undesirable impacts on resources and communities irritate residents and negatively affect their QOL perceptions (CELTH, 2018; Postma and Schmuecker, 2017). Overtourism also gained academic attention (Goesslig et al., 2020; Mihalic, 2020). Research has suggested a triple overtourism model that recognises not only the limited carrying capacities of the pillars of sustainability, but also the limited carrying capacities of socio-psychological and socio-political sustainability, which might be exceeded by overtourism. This triple model extends the narrow concept of tourism sustainability and provides a foundation for a model to address sustainability from the 
perspective of residents' QOL. Using this model, destination management's efficacy was surveyed to monitor the management of overtourism.

Many destinations claim to have sustainable tourism strategies and policies (UNWTO, 2019b), yet tourism development is "not yet close to. . sustainability" (Buckley, 2012, p. 528; Higgins-Desbiolles, 2010; Fletcher et al., 2019). Overtourism has raised the need for destination management to control the unsustainable effects of tourism. It has been suggested that destination management can overcome unsustainable overtourism challenges (WTTC and McKinsey and Company, 2017; UNWTO, 2018).

This paper provides a conceptual model that surveys destination management control of (unsustainable) overtourism from a residents' QOL perspective. The model identifies the causes of resident tourism-related irritation and may assist destination managers to manage these issues. Hypotheses on the direct, indirect and mediator effects of the proposed model's factors were tested. The model was applied to Slovenia's capital, Ljubljana, which has experienced high rates of tourism growth in the past decade and shows characteristics of potential tourism irritation from the perspective of the destination's residents.

The paper provides a review of the literature, presenting overtourism models and concepts related to QOL-centred sustainable tourism, overtourism and tourism management. The research proposes a multiple factor theoretical model to survey if overtourism can be managed. Methodological approaches follow an empirical test of the proposed model on the example of the selected destination which informs discussion. Conclusions are presented including the contributions and limitations of the work, and suggestions for future research.

This paper applies the sustainable and responsible tourism (SRT) concept (Mihalic, 2016). Sustainable tourism reflects the three pillars of sustainability (natural, socio-culutral and economic) and the impact of tourism on these pillars (Bramwell et al., 2017). Responsible tourism refers to the responsibility of implementing sustainable tourism in practice (Goodwin, 2011) and suggests sustainability implementation triggers (awareness, stakeholders and implementation action). As destination management is a means to attain sustainable tourism through strategic leadership, effective governance and efficient implementation (UNWTO, 2019a), appropriate destination management should prevent unsustainable tourism development, including overtourism. The research follows the established tourism terminology on tourism environments and uses the words natural and environmental as synonyms (UNWTO, n.d.).

\section{Literature review}

Ensuring destination residents maintain positive perceptions and attitudes towards tourism is critical for sustainable tourism development (Nunkoo et al., 2019), which is meant to improve QOL. However, inappropriate tourism growth and development, often economically driven, may generate the oversupply of tourism facilities and the overuse of destination socio-cultural and natural resources (Buhalis, 1999). Tourism development plans have primarily focused on the economic interests of tourism focusing on visitor satisfaction and growth rather than resident satisfaction, QOL and sustainable tourism development (Deery et al., 2012; Moscardo, 2009; Rasoolimanesh and Seyfi, 2020). Debate and policies focusing on sustainability have also been limited to trade-offs between the natural and socio-cultural resources and economic outcomes (Bramwell et al., 2017). This view has become the foundation of many sustainable tourism strategies, policies (UNWTO, 2019b) and indicator schemes, resulting in a gap between QOL-centred sustainability intention and implementation (Buckley, 2012; Higgins-Desbiolles, 2010).

Overtourism suggests unsustainable tourism, demonstrated by negative impacts, such as the overuse or damage of the natural and socio-cultural environment, overloading of tourism infra- and superstructure, degraded tourist experience and local resident alienation 
(WTTC and McKinsey and Company, 2017). The UWTO states that ovetrourism has a very negative effect on QOL perceptions (UNWTO, 2018). Goodwin (2016, p. 1) suggests it invokes a feeling within local residents that there are too many visitors and that the QOL in the destination has "deteriorated unacceptably". Goodwin also argued that overtourism "[...] is the opposite of responsible tourism, which is about using tourism to make better places to live [...]" (Goodwin, 2016, p. 1). This implies that tourism has the capacity to improve a destination for residents and tourists alike. Those who manage tourism are responsible for ensuring that local needs are considered and that destinations respond to overtourism. Responsible tourism builds on strategic leadership and governance founded in the principles of sustainability and urges behaviour that results in sustainable (re)action, or according to Goodwin (2011), "respons-ability".

Complementarity between sustainability and responsibility is captured in the SRT model, which defines the conceptual elements and sustainability implementation triggers of sustainable tourism (Mihalic, 2016). The SRT model conceptualises overtourism as having three dimensions (Mihalic, 2020). The first relates to destinations assessing the carrying capacity of the natural, socio-cultural and economic sustainability pillars. The second relates to the socio-psychological aspects of tourism stakeholders, defined as industry opportunities or constraints, visitor satisfaction or dissatisfaction and resident satisfaction or irritation. The socio-phycological carrying capacity of residents reflects a response (satisfaction or irritation) to positive or negative tourism impacts. The third dimension refers to socio-political aspects of SRT awareness, agendas and implementation. This final dimension includes SRT awareness and ethics, strategies and agendas from civil, governmental and political initiatives, media and networks. This could be founded on Goodwin's suggestions for sustainable strategic leadership, governance and responsible behaviour, within the policies and actions of destination management. The conceptual overtourism model (Table 1) provides a foundation for addressing resident irritation caused by overtourism (Goesslig et al., 2020) and may help to access destination management efficacy (WTTC and McKinsey and Company, 2017; UNWTO, 2018). Destination managers can apply the model to measure residents' tourism-related irritation to identify the source and manage (over)tourism.

Research has highlighted a need to assess how destination management can steer tourism activities towards sustainable tourism outcomes (Bramwell, 2017). Destination management is the "[...] coordinated management of all the elements that make up...a sustainable tourism destination" (UNWTO, 2019a, p. 1). Destination management includes strategic leadership, implementation and governance for sustainable tourism (UNWTO, 2019a). Proponents of the view that overtourism can be managed rely on a similar understanding of destination management's role and emphasise sustainable tourism strategy development and implementation. WTTC and McKinsey and Company (2017) suggest destination management for overtourism should include: building a database to properly inform tourism strategy, establishing a tourism strategy for sustainable growth that would mitigate or prevent overcrowding, the involvement of all stakeholders, including local communities and establishing new financial sources to invest in infrastructure and sustainability.

\section{Table 1 Triple overtourism model}

Sustainability pillars carrying capacity

1

1. Economic

2. Socio-cultural

3. Natural (environmental)
Socio-psychological carrying capacity

2

1. Residents

2. Industry

3. Visitors
Socio-political carrying capacity

3

1. Awareness

2. Agendas

3. Actions

Source: Adapted from Mihalic (2020) 
Indicators for destination management remain underdeveloped within the sustainable tourism debate. Sustainability performance studies also suggest there is disagreement about the application of these indicators. The efficacy of destination management has measured impacts based on the three pillars of sustainability (Bramwell et al., 2017). The European Tourism Indicator System (ETIS) is more comprehensive, proposing indicators where tourism management is assessed. Suggested management indicators include one indicator related to tourism policy and measured by the subjects involved in voluntary sustainability schemes, and two indicators related to visitor satisfaction, measuring visitor satisfaction and intention to return (EC, 2016). As management has been traditionally seen as responsible for tourism's natural, socio-cultural and economic impacts, this approach by ETIS partially expands SRT thinking with a tourism responsibility enabler: tourism destination management.

QOL may be the ultimate goal of sustainable development, as it correlates with economic, social and environmental goals (Cusack, 2019) and goes beyond a narrow economic performance approach, such as gross domestic product (Dwyer, 2020). QOL is defined as "[...] human welfare [...] measured by social indicators" (UN, 1997, p. 61). Research has applied opinion-based, social indicator approaches and focused on how tourism development is related to QOL (Boley et al., 2014; Garrod et al., 2012; Hall, 1994; Harrill, 2004; Jamal and Getz, 1995; Lawton and Weaver, 2015; Simmons, 1994; Sharpley, 2014, 2020). This study has proposed a social carrying capacity indicators approach to investigate the impacts of tourism on QOL based on resident perceptions (Moscardo, 2009; Deery et al., 2012).

There has been discussion and debate related to tourism carrying capacity and the negative impacts of mass tourism (Butler, 2019; Wall, 2020; Dwyer, 2018). Carrying capacity incorporates the limits to growth and development debate within a specific space and time frame. Although there have been many studies on ecological and economic carrying capacities, social carrying capacity is yet to be conceptually analysed in depth (Mauerhofer, 2013). Social carrying capacity studies have noted that perceived negative tourism impacts indicate a movement towards social capacity levels (Muler González et al., 2018; Perdue et al., 1990), inspire irritation and tourism opposition among residents and negatively impact QOL, well-being and sustainability. Residents' social carrying capacity defines attitudes towards tourism and may lead to action against the presence tourism and development (Hadinejad et al., 2019). This irritation occurs when residents become concerned about the negative impacts of tourism, including increased competition for destination resources. The irritation carrying capacity depends on many factors. It can be decreased, if residents experience economic or other benefits from tourism. The irritation level can also be reduced by participative governance in the form of resident collaboration or co-creation of tourism development (Buhalis and Sinarta, 2019). The question of "How many is too many?" cannot be easily answered by assessing the ecological and economic pillars of sustainability (Wall, 2020, p. 213). It is also imperative to respond to the question from the perspective of social carrying capacity triggers (Table 1).

Studies have addressed destination social carrying capacity through socio-psychological assessments of residents' tourism perceptions, the impact on QOL and the role of management and governance. Aall and Koens (2019) determined there were tensions between residents' QOL and industry interests, and residents' rejection of tourism has been studied in Barcelona (Martín et al., 2018; Milano et al., 2019). An analysis of Munich's carrying capacity focused on different forms of tourism impact in relation to residents' daily life (Namberger et al., 2019). A resident resistance study in Budapest explored residents' rejection of the 2017 Olympic bid (Smith et al., 2019). In 2016, a study on Ljubljana showed $10 \%$ of city residents considered tourism crowding irritating. The main tourism-related factors affecting residents' QOL were high prices, Airbnb rentals and crowding (Valicon, 2017). Another Ljubljana study, based on a 2017 survey of residents' attitudes towards 
overtourism, found responsibility enablers, such as stakeholder cooperation, had a positive effect on residents' QOL perceptions (Kuščer and Mihalic, 2019). Other studies have also addressed the responsibility for tourism development, including the impact of tourism governance and management in the context of negative tourism impacts (Novy, 2019; TRAN, 2018; UNWTO, 2018; WTTC and McKinsey and Company, 2017). A study by the European Union (EU) (TRAN, 2018, p. 80) found tourism management was limited in its capacity to manage overtourism and that sustainability planning, limiting restaurants, spreading visitors over the city and waste management "[had] positive impacts but did not prevent all symptoms of overtourism".

WTTC and McKinsey and Company (2017) assessed tourism impacts in 68 cities and argued that the negative impacts could potentially be managed, mitigated or prevented. Residents' social carrying capacity (i.e. alienation of local residents) was measured indirectly by quantitative indicators of tourism density and intensity. This methodology suggests that higher tourism density and intensity results in higher resident alienation and irritation. However, a specific number defining density/intensity of sustainable carrying capacity does not exist, as limits are destination-specific and socio-psychological in nature. Social indicators of residents' irritation must be established to determine if overtourism is to be managed.

The UNWTO (2018) studied eight European cities to establish residents' social carrying capacity, based on their perspectives towards visitor growth and future tourism development. The findings suggested that residents recognise tourism's positive and negative QOL impacts and mostly approve of further growth, if properly managed and controlled. Responding to tourism impacts, destinations have limited cruise ship entry (Dubrovnik and Venice), charged fees to enter cities (Venice) or de-marketed tourism (Hawaii and Amsterdam) to reduce visitation and minimise resident irritation (Butler, 2020).

\section{Research construct}

The proposed model aims to understand if overtourism can be managed. From the conceptual overtourism model (Mihalic, 2020), five factors were selected that are relevant to overtourism management in terms of irrationation and QOL of local residents (see Table A1 in Appendix). The first two, positive tourism impacts and negative tourism impacts, represent second-order factors that capture tourism's positive and negative impacts on the destination's natural, socio-cultural and economic resources. The third factor, residents' irritation, captured feelings towards overtourism, and the fourth, QOL, captured tourism's sustainability performance assessed by resident QOL. The fifth, central to this research, was the self-standing factor of destination management (Figure 1).

Hypotheses were grouped and the first group aimed to explore the direct connection between tourism impacts and QOL. The second group focused on the role of destination management and resident irritation and examined the indirect connections between tourism impacts and residents' QOL. The third group tested destination management's capacity to improve residents' QOL. All hypotheses are presented in Figure 1.

\section{Methodology \\ Destination Ljubljana}

Slovenia is located on the Adriatic Sea and is a popular destination because of its natural attractions and cities. Ljubljana is one of the smallest EU capitals and has 288,000 inhabitants (WPR, n.d.). It offers a range of leisure and business accommodation. In 2019, the city received 2.2 million overnight stays, the majority of which were international visitors (ZTL, 2020) and the average stay was approximately two days. In addition to overnight visitors, day visitors come from neighbouring countries or other Slovenian destinations. 


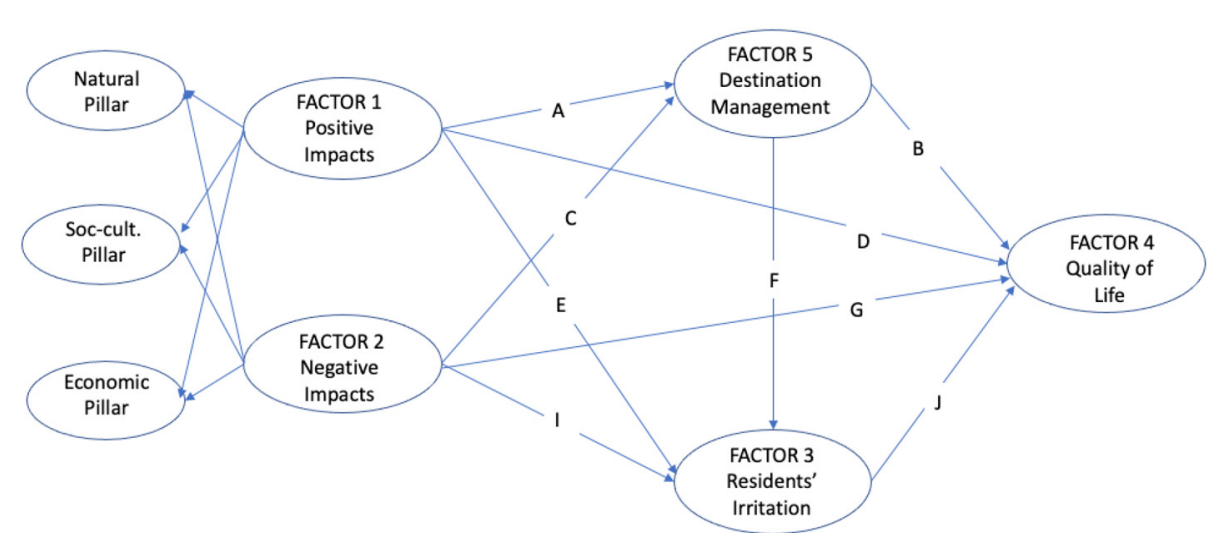

Notes: A, B, C, D E, F, G, I, J name the connections. Hypothesis (H) refers to the different connections and their combinations. Direct connections hypothesis: Hla: D; Hlb: G. Indirect connections hypothesis: H2a: A and B; H2b: C and B; H2c: I and J; H2d: E and J. Mediator hypothesis: H3a: D, A and B; H3b: C, F and I

Source: This study

Tourism attractions are the Ljubljana Castle, the Ljubljana Summer Festival and the downtown area around the river, where people walk or meet in an open-air atmosphere with many cafés and bars.

"Tourism Ljubljana" is a destination management organisation (DMO), a city-established public institution responsible for planning, organising and promoting tourism development (ZTL, 2020). The DMO has developed a city-specific tourism strategy and operational policy plan. Its sustainable vision is twofold. Firstly, Ljubljana strives to become a yearround, internationally attractive, experience-rich, European city destination for active and romantic experiences and business meetings. Secondly, it strives to offer a high QOL and a pleasant atmosphere for inhabitants and visitors. The DMO is responsible for the "awareness and encouragement of the local population for a positive attitude towards tourists and tourism" (ZTL, 2020, p. 3). It monitors residents' tourism-related opinions and its impact on their QOL perceptions, as well as the potential risk of overtourism and irritation (ZTL, 2016, 2017, 2018). It has also successfully applied for many green tourism awards and competitions and promotes these to demonstrate its sustainability as a tourism destination.

With an average annual tourism growth of almost 12\% for 2011-2019 (SORS, 2019), Ljubljana falls in the highest quintile of overtourism risk according to the WTTC and McKinsey and Company's (2017) scale. However, a density of 147,400 tourists per city centre square kilometre places Ljubljana in the fourth quintile, suggesting a low overtourism risk, and a tourism intensity of 2.55 visitors per resident (SORS, 2019) places it in the third quintile. Although these indicators demonstrate an inconsistent overtourism risk, Ljubljana's high tourism growth suggests it is an appropriate case for an overtourism risk analysis.

\section{Research approach and data}

This study used a social constructivist approach to test a five-factor model to better understand overtourism (Druckman, 2001) by applying a survey addressing the pre-set hypotheses. Factors were established through explanatory factor analyses and further tested with structural equation modelling (SEM). A possible list of 56 measurement 
statements (Table A1 in Appendix) was derived from tourism indicators within the literature, such as the ETIS (EC, 2016) and the Sustainable Destination Standard (Green Destinations, 2019), and from previous surveys of tourism impacts in Ljubljana (Kuščer and Mihalic, 2019; Valicon, 2017).

To reduce the risk of non-random measurement errors (Liu and Arnett, 2000), variables were revised for validity, completeness and readability by three academic experts in sustainability impact measurement and three destination managers in Ljubljana. The intensity of agreement or disagreement was rated using a five-point Likert-type scale (1 being "totally disagree" to 5 being "totally agree"). Non-probability quota sampling and face-to-face quantitative interviews were conducted in July and August 2018 with 502 Ljubljana inhabitants (200 city-centre residents and 302 living in other parts of Ljubljana). The sample was representative of age and gender with $48 \%$ of respondents being male $\left(\chi^{2}=0.510 ; p=0.475\right)$. Respondents were evenly distributed by age in comparison with Ljubljana's age distribution (SORS, 2019), and the chi-square test was not significant $\left(\chi^{2}=\right.$ 12.429; $p=0.053$ ). The majority had at least a university education, lived in a two-member household, had a monthly income of $€ 1,001-2,000$ and had been living in Ljubljana for $21-40$ years.

\section{Analysis}

A factor analysis solution yielded 11 factors explaining $62.2 \%$ of the variance (Table 2). Principal axis factoring with promax oblique rotation was applied, allowing for possible correlation among factors (Costello and Osborne, 2005). Variables with loadings below 0.5 and cross-loadings above 0.4 were excluded. For the final model, 32 variables remained (Table 3). All factors exhibited good reliability, indicated by Cronbach's alpha coefficients over 0.7 .

Residents' perceptions of tourism impact in relation to factors tourism superstructure, nature, economy and society, restaurants and bars and culture (Table 2) were positive, while pollution, congestion and prices were regarded negatively. In addition to tourism's positive and negative impacts, the factor analysis produced self-standing factors for Ljubljana's destination management, residents' irritation with tourism presence and impact and residents' QOL. Confirmatory factor analysis was used to test the model. As some factors had only two variables, each pair's regression weight was set to be equal (Kenny, 2012). All regression weights were statistically significant and in the appropriate direction. Furthermore, all factors had sufficient validity, shown by the composite reliability and average variance extracted values being over 0.7 and 0.5 , respectively.

The relationships between factors were surveyed with a path analysis model and a latent model with two second-order latent constructs, tourism's positive and negative impacts,

\begin{tabular}{|c|c|c|c|c|c|c|c|c|c|c|c|}
\hline Factors & 1 & 2 & 3 & 4 & 5 & 6 & 7 & 8 & 9 & 10 & 11 \\
\hline 1. Nature & 1.000 & & & & & & & & & & \\
\hline 2. Culture & 0.578 & 1.00 & & & & & & & & & \\
\hline 3. Economy and society & 0.467 & 0.626 & 1.000 & & & & & & & & \\
\hline 4. Restaurants and bars & 0.134 & 0.379 & 0.199 & 1.000 & & & & & & & \\
\hline 5. Tourism superstructure & 0.462 & 0.561 & 0.574 & 0.346 & 1.000 & & & & & & \\
\hline 6. Pollution & -0.208 & -0.521 & -0.402 & -0.189 & -0.260 & 1.000 & & & & & \\
\hline 7. Congestion & -0.166 & -0.315 & -0.232 & -0.105 & -0.204 & 0.421 & 1.000 & & & & \\
\hline 8. Prices & -0.155 & -0.192 & -0.118 & -0.123 & -0.061 & 0.278 & 0.371 & 1.000 & & & \\
\hline 9. Destination management & 0.550 & 0.593 & 0.469 & 0.353 & 0.455 & -0.250 & -0.231 & -0.139 & 1.000 & & \\
\hline 10. Resident's irritation & -0.298 & -0.539 & -0.577 & -0.156 & -0.316 & 0.617 & 0.475 & 0.312 & -0.319 & 1.000 & \\
\hline 11. QOL & 0.357 & 0.378 & 0.441 & 0.319 & 0.365 & -0.249 & -0.069 & -0.095 & 0.411 & -0.338 & 1.000 \\
\hline
\end{tabular}


Table 3

1. Positive impacts

\section{Nature}

0.767

0.525

Because of tourism, Ljubljana's cleanliness is maintained

0.737

0.646

increased

Tourism contributes to the protection and preservation of nature

in Ljubljana

Culture

Tourism has a positive impact on Ljubljana's characteristics and local identity, culture and heritage

Tourism is the reason for preserving and promoting local culture in Ljubljana

Tourism positively influences Ljubljana inhabitants' cultural

awareness and pride

Economy and society

Increased tourists in the community helps local economic

development

Tourism brings new investments to Ljubljana

The community benefits from tourism and visitors

Restaurants and bars

Bars in the city centre provide high-quality service

City-centre restaurant and bar employees are friendly

Tourism superstructure

Shopping opportunities are better because of tourism

Entertainment opportunities are better because of tourism

Restaurants are better because of tourism

Sports opportunities are better because of tourism

2. Negative impacts

Pollution

Tourism development destroys Ljubljana's green spaces

Visitors pollute Ljubljana with the rubbish that they leave behind

Tourism in Ljubljana causes air pollution

Tourism damages Ljubljana's visual and architectural image

Congestion

Tourism in Ljubljana causes congestion in public urban areas

(pavements and markets)

Tourism in Ljubljana causes congestion in bars and shops

Prices

Because of tourism, life in Ljubljana is more expensive

Prices in city-centre bars and restaurants are high

3. Destination management

Ljubljana has a good organisation that supports the

development of tourism

The public institute Ljubljana Tourism has a well-designed,

resident-friendly tourism development strategy

4. Residents' irritation

Tourist numbers in Ljubljana should be limited

In the seasonal months (June-September), there should be

fewer visitors in Ljubljana

Life in Ljubljana (as a touristic place) is uncomfortable

Because of tourism, I would like to move out of Ljubljana

5. QOL

I am happy to live in Ljubljana

The QOL in Ljubljana is high (in general)

Ljubljana has everything I need

0.784

0.848

0.824

0.829

0.764

0.824

0.866

0.708

0.763

0.750

0.779

0.791

0.739

0.730

0.724

0.821

0.835

0.786

0.595

0.695

0.891

0.856

0.712

0.803

0.818

0.834

0.738

0.834

.

0.611

0.650

3.00

3.47

3.43

3.49

3.49

1.178

1.146

3.82

3.78

1.143

3.90

3.78

3.62

3.54

3.69

3.01

2.86

3.24

3.24

2.70

3.28

2.45

2.41

2.67

2.67

2.06

0.866

0.763

3.44

3.55

3.33

3.95

3.84

4.05

0.811

0.682

3.32

3.45

3.18

1.059

1.142

1.015

0.961

1.271

1.293

1.218

1.160

1.192

1.230

1.193

1.052

1.245

1.292

1.096

0.936

1.005

1.015

0.861

0.608

2.26

2.57

2.38

1.419

0.824

0.751

0.711

0.733

0.765

0.625

Source: Computed from data from ZTL (2018) 
was created (Figure 2). These opposing impacts were negatively correlated. The path analysis showed some hypotheses (Figure 1) could be confirmed. From the second group of hypotheses, one (H2a) on the positive path between positive impacts, tourism management and QOL was confirmed. The residents' irritation factor was connected to positive and negative impacts, and two related hypotheses were confirmed: the path from positive impacts and residents' irritation to QOL $(H 2 d)$ and the path from negative impacts to residents' irritation to QOL $(H 2 c)$. However, no connections from the third hypothesis group were statistically significant.

The goodness-of-fit measures showed the model was statistically a good fit (Table 4). The chisquare was significant, and to overcome sensitivity to sample size, the relative chi-square was calculated. Furthermore, both comparative fit index (CFI) and incremental fit index (IFI) were above 0.9, strengthening the indication, and standardizes root mean square residual (SRMR) and root-mean-squared error of approximation (RMSEA) indicated the same (well below 0.8 and slightly over 0.05, respectively) (Hair et al., 2010; Hu and Bentler, 1999; MacCallum et al., 1996).

\section{Discussion}

The current study, which arose from the question of whether overtourism can be managed, adds to the tourism sustainability performance literature. The proposed five-factor model enabled destination management's direct and mediating role in enhancing QOL to be investigated and was confirmed by the structural equation path model (Figure 2).

The two differing factors on positive and negative tourism impacts were based on the statements, derived from the existing sustainable tourism indicators on economic, sociocultural and natural tourism impacts (Figure 2). Regarding economic sustainability,

\section{Figure 2 Path analysis model results}

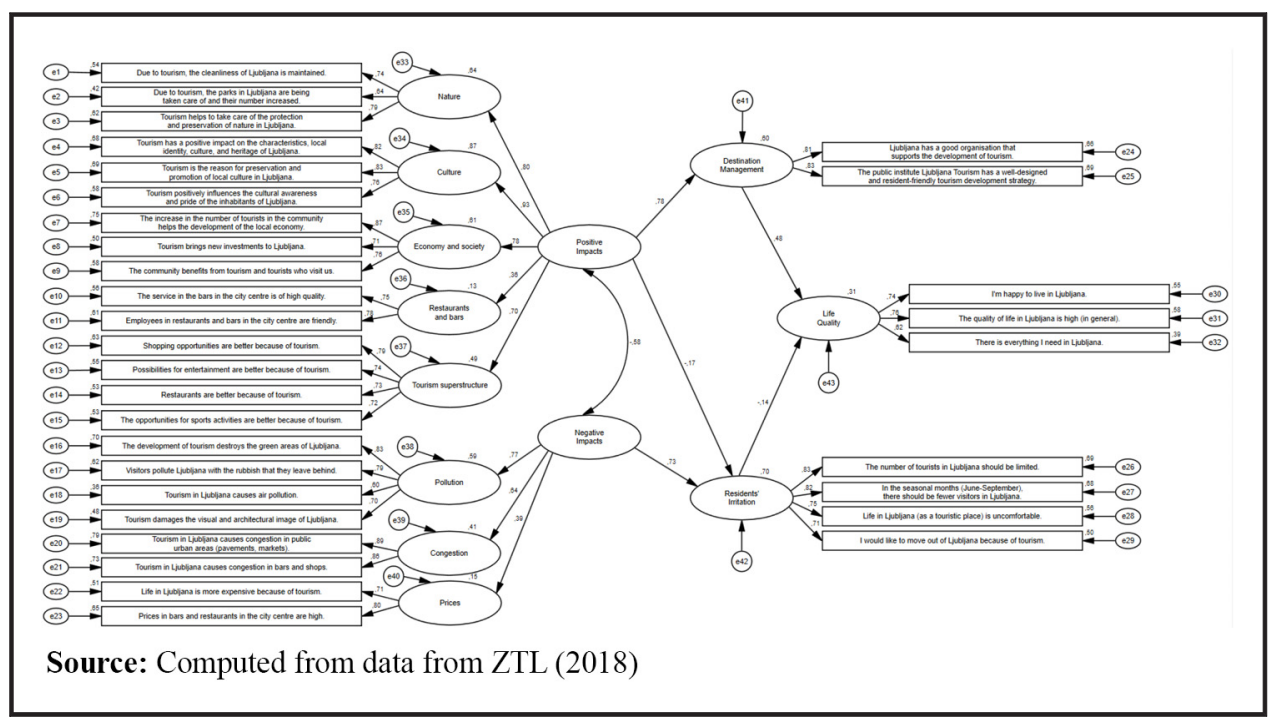

\section{Table 4 Goodness-of-fit measures}

\begin{tabular}{lccccccc}
$\chi 2$ & $\mathrm{p}$ & $d f$ & $\chi 2 / d f$ & CFI & IFI & RMSEA & SRMR \\
\hline 1160.465 & 0.000 & 454 & 2.556 & 0.909 & 0.909 & 0.056 & 0.0602 \\
Source: Computed from data from ZTL (2018) & & &
\end{tabular}


indicators such as local economic development, new investment, social benefits from visitors, restaurant and bar quality, shopping, entertainment and sport opportunities (Figure 2) were all positively related to destination management and residents' QOL. Conversely, negative economic impacts caused resident irritation and showed a negative relationship to QOL. A previous study (Valicon, 2017) indicated that destination management should address tourism's negative economic impacts related to Airbnb presence, increased prices and congestion. The current study confirmed irritation from high prices and overcrowding, but not from Airbnb specifically. Tourism caused congestion in public urban areas and in bars and shops and was perceived to have increased prices in bars and restaurants. The Airbnb-related variable (item 22 in Table A1) was not statistically significant and was not included in the model (Table 3). It is assumed that in 2017, residents considered Airbnb irritating because of the increase in Airbnb facilities and their impact on the real estate market and the availability of rental housing stock for locals. The hotel sector also complained of unfair competition from weak or non-existent safety and regulation standards. Ljubljana's DMO cooperated with private, government and political actors to address this issue, and the current study did not find that there was irritation related to Airbnb, likely because of improvements in related government control.

Regarding natural and socio-cultural sustainability, respondents agreed that "due to tourism, the cleanliness of Ljubljana is maintained". This strongly indicates this tourismrelated service is appreciated by Ljubljana residents and positively impacts on their satisfaction with tourism. It is also consistent with previous findings confirming waste management as a tool to reduce the irritation of overtourism (TRAN, 2018). The model also revealed information about public park maintenance and nature preservation impacted positively on QOL. Respondents also appreciated tourism contributed to culture through local identity, heritage identity, preservation and promotion, as well as cultural awareness and pride. The negative impacts on the natural environment such as green space, air and visual pollution and waste contributed to residents' irritation. The model did not detect any negative impacts of tourism on the Ljubljana's cultural environment.

The model also confirmed that positive impacts reduced residents' impression of overtourism, as positive and negative impacts were negatively correlated. This indicates a degree of trade-off between the benefits and costs of tourism presence and development. For example, tourism's positive economic impacts lower the irritation potential of negative impacts on nature and thus residents' overtourism impression and subsequent negative effect on QOL. Therefore, the sociopsychological tourism carrying capacity and the tourism impact irritation level cannot be generally defined for any destination but needs to be set specifically for each destination and local circumstances. Any efforts to reduce tourism development should be undertaken based on the destination's context and from the standpoint of all stakeholder groups, including residents, visitors, industry, networks, governments, institutions, media or political factors.

The proposed model attempts to assess overtourism with seven social indicators, based on residents' irritation with tourism (Table A1 in Appendix, items 23-25, 30, 31, 36 and 40). The study argues that residents' tourism-related socio-psychological carrying capacity may help to determine when tourism development should be stopped. Nevertheless, the assumption that Ljubljana was an appropriate overtourism case was made based on WTTC's overtourism quantitative measurement scale, which placed Ljubljana into the first category of overtourism risk. The SEM captured four indicators connected to residents' perceptions of too many tourists, high seasonal intensity, discomfort with the presence of tourism and intention to move away from Ljubljana because of tourism irritation. However, none of these indicators reached the midpoint on the five-point Likert scale, indicating that irritation, measured by social indicators, did not put Ljubljana in an overtourism risk category. This may explain the minimal effect of irritation on residents' QOL. The DMO should continue its sustainable tourism management in relation to seasonal and overall tourism growth rates, which represent a potential for overtourism. The study suggests that 
work undertaken by the DMO, and captured by the study's model, supports residentfriendly tourism that has had positive implications for resident's QOL (Figure 2).

Despite the model's statistical significance that enabled study conclusions and the confirmation of some of the hypotheses, the study has failed to confirm tourism management's mediating role. Connections between residents' irritation, destination management and residents' QOL were not confirmed by the empirical model. These findings are partly in line with a previous study (TRAN, 2018) that found that destination management failed to prevent all overtourism impacts. In Ljubljana's case, confirmation of the mediator role would mean that the DMO could limit the number of visitors and reduce visitation during the high season.

This study has confirmed that destination management can address some tourism impacts that cause resident irritation. The survey instrument suggested three destination management variables, one for each of the areas of strategic leadership, efficient policy and governance (Table A2, variables 26, 27 and 33). During the modelling process on the case of Ljubljana, the variable related to resident participation and cooperation (number 33) was excluded. The lack of this variable on cooperation between Ljubljana DMO and city residents may have affected the inability of the Ljubljana empirical model to link destination management and residents' irritation and validate destination management mediator role. Another reason for the mediator confirmation failure may be that tourism irritation is low, as demonstrated by the low mean values of Ljubljana residents' opinions (mean value 2.26, Table 3). In Ljubljana, tourism density is still relatively low and resident's welcome high tourism growth rates. Residents' perceive visitors as contributors to the city superstructure, cleanliness, natural and cultural protection and economic potential.

\section{Conclusion}

This study makes both theoretical and practical contributions. From a theoretical perspective, the model overcomes the narrow three-pillared sustainable tourism perspective and addresses the gap between the principles of sustainable development and its efficient implementation. The model combines the SRT factors, within an overtourism conceptualisation and connects the sustainability pillars and implementation triggers. The concept of sustainability-enabled tourism's positive and negative impacts on economic, socio-cultural and natural sustainability are examined, while the concept of responsibilityenabled resident irritation, QOL and destination management are investigated (Table A1 in Appendix). The model integrates a critical SRT goal, the improvement of residents' tourism (di)satisfaction and QOL and suggests destination management is critical to residents' QOL perceptions. The proposed five-factor model (Figure 1) allows destination managers to monitor the overtourism risk and its causes helping to manage the causes of overtourism irritation and improve residents' QOL.

The proposed theoretical model is the first to move towards a greater understanding of how destination management may have the ability to control unsustainable overtourism from the perspective of residents' irritation and QOL. The model recognises that tourism management's performance and overtourism presence depends not only on tourism growth and impact levels but also on the destination's socio-psychological and socio-political carrying capacity.

This study was limited to destination residents' perceptions. The point at which to halt tourism development cannot be precisely defined as it will depend on stakeholder perceptions, in relation to safeguarding of economic, social, cultural, environmental and political interests. Residents may have differing opinions of how many visitors are too many. This is related to how they perceive the positive and negative impacts of tourism and the flow on implications for well-being and QOL. 
The research can be replicated for any destination by further expanding and adapting the model variables. Destination-specific variables should be added to the tourism impacts list, as relevant. An example variable statement for a cruise destination would be: "The presence of cruise ship groups in the destination bothers me". However, it is expected that the theory-grounded five factors of the proposed overtourism model (Figure 1) would remain the same for all destinations. Future research should address the optimal number of tourists from the socio-psychological perspective of tourists and the tourism industry. Studies of more developed overtourism destinations would be fruitful for future research. Work from these destinations may confirm the mediator role of destination management and its capacity to manage overcrowding, by limiting visitation and tourism growth. Studies are also needed to test the generalisability of the proposed research model and confirm the research hypotheses related to the capacity of destination management to manage tourism.

\section{References}

Aall, C. and Koens, K. (2019), "The discourse on sustainable urban tourism: the need for discussing more than overtourism”, Sustainability, Vol. 11 No. 15, pp. 1-12, doi: 10.3390/su11154228.

Boley, B.B., McGehee, N.G., Perdue, R.R. and Long, P. (2014), "Empowerment and resident attitudes toward tourism: strengthening the theoretical foundation through a weberian lens", Annals of Tourism Research, Vol. 49, pp. 33-50, doi: 10.1016/j.annals.2014.08.005.

Bramwell, B., Higham, J., Lane, B. and Miller, G. (2017), "Twenty-five years of sustainable tourism and the journal of sustainable tourism: looking back and moving forward", Journal of Sustainable Tourism, Vol. 25 No. 1, pp. 1-9, doi: 10.1080/09669582.2017.1251689.

Buckley, R. (2012), "Sustainable tourism: research and reality", Annals of Tourism Research, Vol. 39 No. 2, pp. 528-546, doi: 10.1016/j.annals.2012.02.003.

Buhalis, D. (1999), "Limits of tourism development in peripheral destinations: problems and challenges", Tourism Management, Vol. 20, pp. 183-185.

Buhalis, D. and Sinarta, Y. (2019), "Real-time co-creation and nowness service: lessons from tourism and hospitality", Journal of Travel \& Tourism Marketing, Vol. 36 No. 5, pp. 563-582, doi: 10.1080/ 10548408.2019.1592059.

Butler, R. (2019), "Overtourism and the tourism area life cycle", in Dodds, R. and Butler, R.W. (Eds). Overtourism: Issues, Realities and Solutions, Walter de Gruyter GmbH, Berlin/Boston, pp. 250-261.

Butler, R. (2020), "Tourism carrying capacity research: a perspective article", Tourism Review, Vol. 75 No. 1, pp. 207-211, doi: 10.1108/TR-05-2019-0194.

CELTH (2018), Visitor Pressure and Events in an Urban Setting. Understanding and Managing Visitor Pressure in Seven European Urban Tourism Destinations, Centre of Expertise in Leisure, Tourism \& Hospitality, Breda.

Costello, A.B. and Osborne, J.W. (2005), "Best practices in exploratory factor analysis: four recommendations for getting the most from your analysis", practical assessment", Research \& Evaluation, Vol. 10 No. 7, pp. 173-178.

Cusack, C. (2019), "Sustainable development and quality of life", in Sinha, B. (Ed.), Multidimensional Approach to Quality of Life Issues, Springer, Singapore, pp. 43-58.

Deery, M., Jago, L. and Fredline, L. (2012), "Rethinking social impacts of tourism research: a new research agenda", Tourism Management, Vol. 33 No. 1, pp. 64-73, doi: 10.1016/j.tourman.2011.01.026.

Druckman, J.N. (2001), "The implications of framing effects for citizen competence", Political Behavior, Vol. 23 No. 3, pp. 225-256, doi: 10.1023/A:1015006907312.

Dwyer, L. (2018), "Saluting while the ship sinks: the necessity for tourism paradigm change", Journal of Sustainable Tourism, Vol. 26 No. 1, pp. 29-48, doi: 10.1080/09669582.2017.1308372.

Dwyer, L. (2020), "Tourism development and sustainable well-being: a beyond GDP perspective", Journal of Sustainable Tourism, doi: 10.1080/09669582.2020.1825457. published online,

EC (2016), "The European tourism indicator system", ETIS Toolkit for Sustainable Destination Management, European Commission, Luxembourg. 
Fletcher, R., Murray Mas, I., Blanco-Romero, A. and Blázquez-Salom, M. (2019), "Tourism and degrowth: an emerging agenda for research and praxis", Journal of Sustainable Tourism, Vol. 27 No. 12, pp. 1745-1763, doi: 10.1080/09669582.2019.1679822.

Garrod, B., Fyall, A., Leask, A. and Reid, E. (2012), "Engaging residents as stakeholders of the visitor attraction", Tourism Management, Vol. 33 No. 5, pp. 1159-1173, doi: 10.1016/j.tourman.2011.11.014.

Goesslig, S., McCabe, S. and Chen, N.C. (2020), "A socio-psychological conceptualisation of overtourism", Annals of Tourism Research, Vol. 84, p. 102976, doi: 10.1016/j.annals.2020.102976.

Goodwin, H. (2011), Taking Responsibility for Tourism, Goodfellow Publishers Limited, Oxford.

Goodwin, H. (2016), "Overtourism: what is it and how do we address it?", available at: https:// responsibletourismpartnership.org/overtourism/ (accessed 10 September 2020).

Green Destinations (2019), "Green destination standard", available at: https://greendestinations.org/ green-destinations-standard/ (accessed 6 December 2019).

Hadinejad, A., Moyle, B.D., Scott, N., Kralj, A. and Nunkoo, R. (2019), "Residents' attitudes to tourism: a review", Tourism Review, Vol. 74 No. 2, pp. 157-172, doi: 10.1108/TR-01-2018-0003.

Hair, J.F., Black, W.C., Babin, B.J. and Anderson, R.E. (2010), Multivariate Data Analysis, (7th ed.). Prentice Hall, Upper Saddle River.

Hall, C.M. (1994), Tourism and Politics, Policy, Power and Place, John Wiley \& Sons, Chichester, UK/ New York, NY.

Harrill, R. (2004), "Residents' attitudes toward tourism development: a literature review with implications for tourism planning", Journal of Planning Literature, Vol. 18 No. 3, pp. 251-266, doi: 10.1177/ 0885412203260306.

Higgins-Desbiolles, F. (2010), "The elusiveness of sustainability in tourism: the culture-ideology of consumerism and its implications", Tourism and Hospitality Research, Vol. 10 No. 2, pp. 116-115, doi: 10.1057/thr.2009.31

Hu, L. and Bentler, P.M. (1999), "Cutoff criteria for fit indexes in covariance structure analysis: conventional criteria versus new alternatives", Structural Equation Modeling: A Multidisciplinary Journal, Vol. 6 No. 1, pp. 1-55, doi: 10.1080/10705519909540118.

Jamal, T.B. and Getz, D. (1995), "Collaboration theory and community tourism planning", Annals of Tourism Research, Vol. 22 No. 1, pp. 186-204, doi: 10.1016/0160-7383(94)00067-3.

Kenny, D.A. (2012), "SEM: identification", available at: http://davidakenny.net/cm/identify.htm (accessed 11 December 2019).

Kuščer, K. and Mihalic, T. (2019), "Residents' attitudes towards overtourism from the perspective of tourism impacts and cooperation - the case of Ljubljana", Sustainability, Vol. 11 No. 6, p. 1823, doi: 10.3390/su11061823.

Lawton, L. and Weaver, D.W. (2015), 'Using residents' perceptions research to inform planning and management for sustainable tourism: a study of Gold Coast schoolies week, a contentious tourism event", Journal of Sustainable Tourism, Vol. 23 No. 5, pp. 1-23, doi: 10.1080/09669582.2014.991398.

Lew, A.A. (2020), "The global consciousness path to sustainable tourism: a perspective paper", Tourism Review, Vol. 75 No. 1, pp. 69-75, doi: 10.1108/TR-07-2019-0291.

Liu, C. and Arnett, K.P. (2000), "Exploring the factors associated with web site success in the context of electronic commerce", Information \& Management, Vol. 38 No. 1, pp. 23-33, doi: 10.1016/S0378-7206 (00)00049-5

MacCallum, R.C., Browne, M.W. and Sugawara, H.M. (1996), "Power analysis and determination of sample size for covariance structure modelling", Psychological Methods, Vol. 1 No. 2, pp. 130-149, doi: 10.1037/1082-989X.1.2.130.

Martín, J.M.M., Martinez, J.M.G. and Fernández, J.A.S. (2018), "An analysis of the factors behind the citizen's attitude of rejection towards tourism in a context of overtourism and economic dependence on this activity", Sustainability, Vol. 10 No. 8, p. 2851, doi: 10.3390/su10082851.

Mauerhofer, V. (2013), "Social capital, social capacity and social carrying capacity: perspectives for the social basics within environmental sustainability", Futures, Vol. 53 No. 53, pp. 63-73.

Mihalic, T. (2016), "Sustainable-responsible tourism discourse: towards 'responsustable' tourism", Journal of Cleaner Production, Vol. 111 No. Part B, pp. 461-470, doi: 10.1016/j.jclepro.2014.12.062. 
Mihalic, T. (2020), "Conceptualising overtourism: a sustainability approach", Annals of Tourism Research, Vol. 84, pp. 103025, doi: 10.1016/j.annals.2020.103025.

Milano, C., Novelli, M. and Cheer, J.M. (2019), "Overtourism and degrowth: a social movements perspective", Journal of Sustainable Tourism, Vol. 27 No. 12, pp. 1857-1875, doi: 10.1080/ 09669582.2019.1650054.

Moscardo, G. (2009), "Tourism and quality of life: towards a more critical approach", Tourism and Hospitality Research, Vol. 9 No. 2, pp. 159-170, doi: 10.1057/thr.2009.6.

Muler González, V., Coromina Soler, L. and Galí Espelt, N. (2018), "Overtourism: residents' perceptions of tourism impact as an indicator of resident social carrying capacity - case study of a spanish heritage town", Tourism Review, Vol. 73 No. 3, pp. 277-296, doi: 10.1108/TR-08-2017-0138.

Namberger, P., Jackisch, S., Schmude, J. and Karl, M. (2019), "Overcrowding, overtourism and local level disturbance: how much can Munich handle?", Tourism Planning \& Development, Vol. 16 No. 4, pp. 452-472, doi: 10.1080/21568316.2019.1595706.

Novy, J. (2019), "Urban tourism as a bone of contention: four explanatory hypotheses and a caveat", International Journal of Tourism Cities, Vol. 5 No. 1, pp. 63-74, doi: 10.1108/IJTC-01-2018-0011.

Nunkoo, R., Seetanah, B. and Agrawal, S. (2019), "Guest editorial: innovations in sustainable tourism research", Tourism Review, Vol. 74 No. 2, pp. 129-137, doi: 10.1108/TR-04-2019-209.

Perdue, R.R., Long, P.T. and Allen, L. (1990), "Resident support for tourism development", Annals of Tourism Research, Vol. 17 No. 4, pp. 586-599, doi: 10.1016/0160-7383(90)90029-Q.

Postma, A. and Schmuecker, D. (2017), "Understanding and overcoming negative impacts of tourism in city destinations: conceptual model and strategic framework", Journal of Tourism Futures, Vol. 3 No. 2, pp. 144-156, doi: 10.1108/JTF-04-2017-0022.

Rasoolimanesh, S.M. and Seyfi, S. (2020), "Residents' perceptions and attitudes towards tourism development: a perspective article", Tourism Review, doi: 10.1108/TR-11-2019-0461.

Sharpley, R. (2014), "Host perceptions of tourism: a review of the research", Tourism Management, Vol. 42 No. 1, pp. 37-49, doi: 10.1016/j.tourman.2013.10.007.

Sharpley, R. (2020), "Tourism, sustainable development and the theoretical divide: 20 years on", Journal of Sustainable Tourism, Vol. 28 No. 11, pp. 1932-1946, doi: 10.1080/09669582.2020.1779732.

Simmons, D.G. (1994), "Community participation in tourism planning", Tourism Management, Vol. 15 No. 2, pp. 98-108, doi: 10.1016/0261-5177(94)90003-5.

Smith, M.K., Sziva, I.P. and Olt, G. (2019), "Overtourism and resident resistance in Budapest", Tourism Planning \& Development, Vol. 16 No. 4, pp. 376-392, doi: 10.1080/21568316.2019.1595705.

SORS (2019), "SiSat database", Statistical Office of the Republic of Slovenia (SORS)", available at: http:// pxweb.stat.si/pxweb/Database/Ekonomsko/Ekonomsko.asp (accessed 6 October 2019).

TRAN (2018), Research for TRAN Committee - Overtourism: Impact and Possible Policy Responses, European Parliament, Policy Department for Structural and Cohesion Policies, Luxembourg.

UN (1997), "Glossary of environment statistics", Studies in Methods, Series F, No. 67, United Nations (UN). New York.

UNWTO (2018), 'Overtourism'? Understanding and Managing Urban Tourism Growth beyond Perceptions, United Nations World Tourism Organization (UNWTO). Madrid.

UNWTO (2019a), "Destination management. Policy and destination management, United Nations World Tourism Organization (UNWTO)", available at: www.unwto.org/policy-destination-management (accessed 20 November 2019).

UNWTO (2019b), International Tourism Highlights. 2019 Edition, United Nations World Tourism Organization (UNWTO). available at: www.e-unwto.org/doi/pdf/10.18111/9789284421152 (accessed 11 April 2020).

UNWTO (n.d.). "Sustainable development of tourism. Definition. United Nations World Tourism Organization (UNWTO)", available at: www.unwto.org/sustainable-development (accessed 10 October 2020)

Valicon (2017), Odnos Meščanov Do Turizma. Poročilo Raziskave. (Engl.: Attitudes of Citizens towards Tourism. Research Report.), 2017, TLJ104, Valicon, Ljubljana. 
Wall, G. (2020), "From carrying capacity to overtourism: a perspective article", Tourism Review, Vol. 75 No. 1, pp. 212-215, doi: 10.1108/TR-08-2019-0356.

WPR (n.d.), "Ljubljana population 2020", World Population Review, available at: https:// worldpopulationreview.com/world-cities/ljubljana-population/ (accessed 10 May 2020).

WTTC and McKinsey and Company (2017). "Coping with success: managing overcrowding in tourism destinations", World Travel \& Tourism Council (WTTC), available at: www.mckinsey.com/ /media/ mckinsey/industries/travel\%20transport\%20and\%20logistics/our\%20insights/coping\%20with\% 20 success\%20managing\%20 vercrowding\%20in\%20tourism\%20destinations/coping-with-successmanaging-overcrowding-in-tourism-destinations. ashx (accessed 11 May 2020).

ZTL (2016), Database on TLJ 2016, Zavod Turizem Ljubljana, Ljubljana.

ZTL (2017), Database on TLJ 2017, Zavod Turizem Ljubljana, Ljubljana.

ZTL (2018), Database on TLJ 2017, Zavod Turizem Ljubljana, Ljubljana.

ZTL (2020), Poslovni Načrt Turizma Ljubljana za Leto 2020 (Engl.: Ljubljana Tourism Business Plan for 2020), Zavod Turizem Ljubljana, Ljubljana. 


\section{Appendix}

Table A1 Research construct from triple overtourism model

Sustainability pillars carrying capacity

1

Economic, socio-cultural, natural:

Factor 1: Positive impacts

Factor 2: Negative impacts

Source: Adapted from Table 1
Socio-psychological carrying capacity

2

Factor 3: Residents' irritation

Factor 4:

QOL of residents
Socio-political carrying capacity 3

Factor 5: Destination management 
No.

The QOL in Ljubljana is high (in general)

I am happy to live in Ljubljana

Ljubljana has everything I need

I would move out of Ljubljana if I could improve my living or working conditions

Tourism development contributes to Ljubljana's development

I support tourism's further growth and development

I am satisfied with the tourism in Ljubljana

In general, tourism's positive effects outweigh its negative effects in Ljubljana

Tourism brings new investments to Ljubljana

Increased tourists in the community helps local economic development

The community benefits from tourism and visiting tourists

I and my family benefit from tourism and visiting tourists

Sports opportunities are better because of tourism

Shopping opportunities are better because of tourism

Entertainment opportunities are better because of tourism

Restaurants are better because of tourism

Bars in the city centre provide high-quality service

Prices in city-centre bars and restaurants are high

Because of tourism, life in Ljubljana is more expensive

Because of tourism, land and real estate prices are rising

Ljubljana needs more hotels.

Airbnb or new forms of tourist accommodation bother me

Tourist numbers in Ljubljana should be limited

In the seasonal months (June-September), there should be fewer visitors in Ljubljana

In the off-season months (October-May), there should be more visitors in Ljubljana

Ljubljana has a good organisation that supports tourism development

The public institute Ljubljana Tourism has a well-designed, resident-friendly tourism development strategy

Tourism has a positive impact on Ljubljana's characteristics and local identity, culture and heritage

Tourism contributes to a better QOL in Ljubljana

Life in Ljubljana (as a touristic place) is uncomfortable

Because of tourism, I would like to move out of Ljubljana

When planning tourism in Ljubljana, citizens' QOL is considered

In general, I am satisfied with residents' involvement and influence in tourism planning and development

The offer of local food in Ljubljana restaurants is good

City-centre restaurant and bar employees are friendly

City-centre residents feel cramped

I am pleased Ljubljana is an attractive place for visitors

Tourism is the reason for preserving and promoting local culture in Ljubljana

Public services and city infrastructure are better because of tourism

The increase in tourism leads to conflict between visitors and locals

Because of tourism in Ljubljana, crime is rising

Tourism in Ljubljana causes congestion in bars and shops

Tourism in Ljubljana causes congestion in public urban areas (pavements and markets)

Tourism positively influences Ljubljana inhabitants' cultural awareness and pride

I am satisfied with the offer of various events in the city centre

Tourism in Ljubljana is accessible to people with a disability

Tourism contributes to the protection and preservation of nature in Ljubljana

Tourism in Ljubljana causes air pollution

Tourism development increases traffic problems in Ljubljana

I support Ljubljana's city centre being closed to traffic

Tourism damages Ljubljana's visual and architectural image

Visitors pollute Ljubljana with rubbish they leave behind

Tourism development destroys Ljubljana's green spaces

Because of tourism, Ljubljana's parks are being cared for and increased

Because of tourism, Ljubljana's cleanliness is maintained

I am bothered by night noise from tourism

Source: ZTL (2018) 


\section{About the authors}

Tanja Mihalic is a Professor at the Department of Economics at the School of Economics and Business at the University of Ljubljana (SEBLU), Slovenia. Her research includes tourism economics and policy, sustainability, responsibility, competitiveness, over- and under-tourism and tourism values. She was a Member of the UNWTO World Committee on Tourism Ethics. She is an active member of editorial boards of many academic journals. Tanja Mihalic is the corresponding author and can be contacted at: tanja.mihalic@ef.uni-lj.si

Kir Kuščer is an Assistant Professor at the School of Economics and Business, University of Ljubljana. In his research, he specialises on overtourism, mountain tourism, innovativeness and development. He was a partner in INTERREG IVC project (Digital Agenda for New Tourism Approach in European Rural and Mountain Areas).

For instructions on how to order reprints of this article, please visit our website: www.emeraldgrouppublishing.com/licensing/reprints.htm

Or contact us for further details: permissions@emeraldinsight.com 